\title{
Évreux - 11 rue de l'Horloge
}

$\mathrm{n}^{\circ} 17-899$

\section{Pierre Wech}

\section{(2) OpenEdition}

\section{Journals}

Édition électronique

URL : http://journals.openedition.org/adlfi/16550

ISSN : 2114-0502

Éditeur

Ministère de la culture

Référence électronique

Pierre Wech, «Évreux - 11 rue de l'Horloge », ADLFI. Archéologie de la France - Informations [En ligne], Haute-Normandie, mis en ligne le 17 février 2016, consulté le 19 avril 2019. URL : http:// journals.openedition.org/adlfi/16550

Ce document a été généré automatiquement le 19 avril 2019

(C) Ministère de la Culture et de la Communication, CNRS 


\section{Évreux - 11 rue de l'Horloge}

n'17-899

\section{Pierre Wech}

Lien Atlas (MCC) :

http://atlas.patrimoines.culture.fr/atlas/trunk/index.php?

ap_theme=DOM_2.01.02\&ap_bbox=1.090;48.989;1.190;49.047

1 Le projet d'extension de la Caisse d'Allocations Familiales d'Évreux a nécessité la réalisation d'un diagnostic. La situation de la parcelle par rapport au contexte archéologique et historique de l'agglomération, dans l'enceinte du castrum tardo-antique, rendait très probable la découverte de structures liées au passé gallo-romain et médiéval d'Évreux. L'une des questions principales tenait à la reconnaissance des niveaux d'apparition des vestiges pour déterminer l'impact des travaux projetés.

2 Il s'est avéré que les périodes médiévales et modernes étaient essentiellement représentées par des remblais peu structurés, présentant une épaisseur totale de près de deux mètres, et assimilables à des «terres noires ». Ces remblais, pauvres en mobilier, surmontaient des niveaux gallo-romains structurés, dans lesquels ont été reconnus au moins un mur, des remblais de démolition et un possible niveau de sol. Les profondeurs de terrassement nécessaires et les normes de sécurité induites ne nous ont malheureusement pas permis de réaliser d'observation plus détaillée de ces niveaux qui ont cependant livré, en regard de la très faible surface explorée (moins de $4 \mathrm{~m}^{2}$ ), un abondant mobilier céramique, des enduits peints, des éléments d'architecture et une statuette de Vénus Anadyomène en terre cuite. L'ensemble évoque une occupation datée des III $^{\mathrm{e}}-\mathrm{IV}^{\mathrm{e}}$ s. apr. J.-C. 


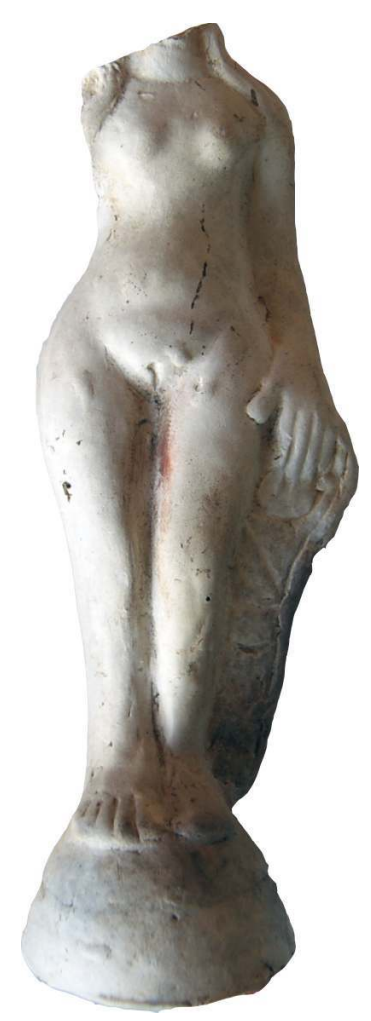

Fig. 01

statuette en terre cuite de Vénus Anadyomène

P. Wech

INDEX

anthroponyme Vénus Anadyomène

Index géographique : Normandie, Eure (27), Évreux

operation Diagnostic (EV)

Index chronologique : Antiquité, Moyen Âge, Temps Modernes

Mots-clés : démolition, terre noire, remblai, enduit peint, statuette

\section{AUTEURS}

\section{PIERRE WECH}

Mission Archéologique de l'Eure 